\title{
Evidence for differential effects of sulphasalazine on systemic and mucosal immunity in rheumatoid arthritis
}

\author{
Lars Kanerud, Gunilla Norhagen Engström, Andrej Tarkowski
}

\begin{abstract}
Objective-To study the effects of sulphasalazine (SASP) on the systemic and mucosal humoral immune systems in patients with rheumatoid arthritis (RA).

Methods-Serum concentrations of interleukin 6 (IL-6), class and subclass specific IgG, IgA and IgM, IgA and IgG antigliadin antibodies and rheumatoid factors (RF) of IgG, IgA (including IgA1 and IgA2 subclasses) and IgM isotypes were measured before and 16 weeks after sulphasalazine (SASP) therapy in 15 female and three male patients with RA. Amounts of immunoglobulins in saliva and jejunal fluid were measured as estimates of mucosal humoral immunity. Results-Serum concentrations of IgA and IgG decreased significantly during SASP therapy and correlated with reduced concentrations of IL-6. In addition, levels of circulating IgA RF, IgA anti-gliadin antibodies and IgM RF decreased significantly after the treatment. In contrast, immunoglobulin levels in saliva and jejunal fluid were unaltered. Conclusion-SASP exerts powerful but selective inhibitory effects on systemic immunoglobulin production, whereas no effects on mucosal immunoglobulin production were observed. The decreased systemic B cell activity may be mediated by downregulation of the production of IL-6, a cytokine with Ig switching properties.
\end{abstract}

(Ann Rheum Dis 1995; 54: 256-262)

Department of

Karolinska Institute, Stockholm Söder Hospital, Sweden L Kanerud

Department of Immunology, Microbiology, Pathology and Infectious Diseases,

Huddinge University Hospital, Huddinge, Sweden

G N Engström

Department of

Rheumatology and

Clinical Immunology,

Gothenburg

University, Sweden

A Tarkowski

Correspondence to:

Dr Lars Kanerud,

Department of

Rheumatology, Stockholm

Söder Hospital, S-118 83

Stockholm, Sweden.

Accepted for publication

17 November 1994 proposal of an enteric cause of RA, ${ }^{12}$ findings that certain dietary antigens exacerbate symptoms in $\mathrm{RA},{ }^{13}$ and more recent obser- vations that some patients with RA display ileocaecal inflammation. ${ }^{14}$ SASP has been shown to decrease intestinal inflammation in RA patients. ${ }^{15}$

The mucosal immune system is considered to be the major immunoglobulin forming organ in the human body. ${ }^{16}$ The intestinal immunocytes produce mainly secretory $\operatorname{IgA}(\operatorname{Ig} \mathrm{A}),{ }^{17}$ and are frequently triggered by orally delivered antigens. ${ }^{18} 19$ Occurrence of IgA rheumatoid factor (RF) has been linked to RA with systemic manifestations, an erosive disease course, or a severe disease outcome. ${ }^{20-23} \operatorname{IgA}$ RF has been shown to be produced in the mucosal compartments, ${ }^{24}{ }^{25}$ and is suggested to be a marker of inflammation in or near mucosal membranes. ${ }^{26}$ Activation of the mucosal immune system should therefore be considered in the pathogenesis of RA.

To study in vivo if the administration of SASP affected humoral immunity in the gastrointestinal tract and peripheral blood in RA patients, we prospectively analysed the concentrations of major classes and subclasses of immunoglobulins in serum, saliva, and jejunal fluid, in addition to the serum levels and isotypic distribution of RF and anti-gliadin antibodies before and after 16 weeks of treatment with sulphasalazine.

\section{Patient and methods}

We studied 21 patients ( 17 female) with clinically active RA, fulfilling the criteria of the American Rheumatism Association for the diagnosis of classical or definite RA. ${ }^{27}$ Previous records showed that the patients were all seropositive for rheumatoid factor. Apart from their RA, the patients were healthy and none complained of gastrointestinal symptoms. Their median age was 54 years (range 24-71) and the median duration of the disease was 73 months (range 6-204).

Clinically active disease was defined as the presence of at least two of the following three criteria: duration of morning stiffness $\geqslant 60$ minutes, tenderness, swelling, or both, of at least six joints, and Westergren erythrocyte sedimentation rate $(E S R) \geqslant 30 \mathrm{~mm} / 1 \mathrm{st} \mathrm{h}$.

None of the patients had received treatment with disease modifying antirheumatic drugs or corticosteroids for at least three months before inclusion in the study.

All patients had given their informed consent before the study, which was approved by the local Ethics Committee. 
STUDY DESIGN

The patients were recruited for a larger study of the gut in RA and the effects of SASP, reported in part elsewhere, ${ }^{28}$ and were treated with SASP $1 \cdot 5-3 \mathrm{~g} /$ day. Before treatment was commenced and 16 weeks thereafter, peripheral blood was drawn and analysed for contents of immunoglobulins (major classes and subclasses), rheumatoid factors, anti-gliadin antibodies, acute phase reactants, and interleukin 6 (IL-6). Saliva and jejunal fluid for immunoglobulin analysis were collected in association with duodenal-jejunal mucosal biopsy sampling at the same times, and disease activity was assessed with an index based on Lansbury's joint index, the duration of morning stiffness, and the ESR. ${ }^{28}$ All samples were collected between 08:00 and 10:00 after an overnight fast.

\section{CLASS AND SUBCLASS SPECIFIC}

DETERMINATIONS OF SERUM

IMMUNOGLOBULINS

Serum concentrations of $\operatorname{IgG}, \operatorname{IgA}, \operatorname{IgM}$, and orosomucoid were determined by turbidometry on a Multistat III centrifugal analyser (Instrumentation Laboratory Ltd, Warrington, UK), using antiserum from Dakopatts (Copenhagen, Denmark) and protein calibrators from Behringwerke (Marburg, Germany). The reference values for IgG, IgA, $\operatorname{IgM}$, and orosomucoid were $7 \cdot 0-15 \cdot 0$, $0 \cdot 7-3 \cdot 5,0 \cdot 2-2 \cdot 2$, and $0 \cdot 4-1 \cdot 1 \mathrm{~g} / \mathrm{l}$, respectively.

IgG subclass concentrations were determined according to routine methods using Mancini immunodiffusion. The reference values for IgG1, IgG2, IgG3, and IgG4 were $4 \cdot 22-12 \cdot 9, \quad 1 \cdot 17-7 \cdot 47, \quad 0 \cdot 41-1 \cdot 29, \quad$ and $0 \cdot 00-2 \cdot 91 \mathrm{~g} / \mathrm{l}$, respectively.

Total concentrations of serum IgA subclasses were determined by enzyme linked immunosorbent assay (ELISA) as previously described. ${ }^{29}$ Briefly, serial dilutions of IgA1 (Pet) and IgA2 (Fel) purified myeloma standards (a generous gift from Dr Jiri Mestecky, Birmingham, AL, USA) and serum samples, all in phosphate buffered saline (PBS) $-10 \%$ fetal calf serum (FCS), were incubated overnight in 96 well polystyrene microtitre plates (Dynatech, Alexandria, VA, USA) coated with $5 \mu \mathrm{g} / \mathrm{ml}$ monoclonal antiIgA1 or anti-IgA2 (Nordic Laboratories, Tilburg, Netherlands) and blocked with PBSFCS. After incubation and washing, biotin conjugated $\mathrm{F}\left(\mathrm{ab}^{\prime}\right)_{2}$ fragments of affinity purified goat anti-human IgA (Tago, Burlingame, CA, USA) diluted 1:1500 in PBSTween containing $10 \%$ FCS were added to the microtitre plates, followed by incubation with $1 \mu \mathrm{g} / \mathrm{ml}$ of horseradish peroxidase labelled avidin (Sigma Chemical Company, St Louis, MO, USA) and, finally, the enzyme substrate $2 \cdot 2$ azino-bis (3-ethyl-benzthiazoline-6-sulphonic acid) (Sigma) in citrate buffer, $\mathrm{pH} 4 \cdot 2$, containing $0.0075 \%$ hydrogen peroxide $\left(\mathrm{H}_{2} \mathrm{O}_{2}\right)$. The absorbance was measured in a Titertek Multiscan photometer (Flow, McLean, VA, USA) at $414 \mathrm{~nm}$. All samples were run in duplicate. Optical density (OD) values were converted to $\mathrm{g} / \mathrm{l}$ using calibration curves based on the OD obtained from serial dilutions of the respective highly purified IgA myeloma proteins. Calibration curves were constructed using a computer program based on the weighted logit-log model. ${ }^{30}$

DETERMINATION OF SERUM IL-6 LEVELS

Serum levels of IL-6 were determined by a bioassay as previously described. ${ }^{31}$ Briefly, we used B9 subclone ${ }^{32}$ originating from cell line B $13 \cdot 29$, which is dependent on IL-6 for growth. B9 cells were harvested from tissue culture flasks, seeded into microtitre plates (Nunc, Roskilde, Denmark) at a concentration of 5000 cells per well, and cultured in Isocove's medium supplemented with $5 \times 10^{-5} \mathrm{~mol} / \mathrm{l}$ 2-mercaptoethanol, 5\% FCS, and $50 \mu \mathrm{g} / \mathrm{ml}$ gentamycin. Heat inactivated serially diluted serum samples and recombinant human IL-6 standard (Genzyme, Cambridge, MA, USA) were added to the wells. 3H-Thymidine was added after 68 hours of culturing, and the cells were harvested four hours later. All samples were run in triplicate. The sensitivity limit for this assay is below $1 \mathrm{pg} / \mathrm{ml}$. B9 cells were previously shown not to react with several recombinant cytokines, including IL- $1 \alpha$ and $\beta$, IL-2, IL-3, IL-5, granulocyte macrophage colony stimulating factor, tumour necrosis factor $\alpha$ and interferon gamma. There was only weak reactivity with $\mathrm{IL}-4 .^{33}$

SALIVA AND JEJUNAL ASPIRATE

Unstimulated whole saliva was collected in the morning after overnight fasting by direct expectoration into a sterile plastic container and was kept at $-70^{\circ} \mathrm{C}$ until required for analysis. In order to obtain jejunal aspirate with a minimum of microbial contamination from the stomach and oral cavity, a special closed tube system (RHP-12·0, William Cook Europe $\mathrm{AB}$, Bjaeverskov, Denmark) was used, as described earlier. ${ }^{34}$ The tube system was attached to the biopsy collecting device during intubation and clearly visualised fluoroscopically. Aspirate was collected from the proximal part of jejunum immediately before biopsy sampling and thereafter kept in plastic tubes at $-70^{\circ} \mathrm{C}$ until analysis.

DETERMINATION OF IMMUNOGLOBULINS IN SALIVA AND JEJUNAL ASPIRATE

The saliva and jejunal samples were thawed and centrifuged for 15 minutes at $10000 \mathrm{~g}$ at $4^{\circ} \mathrm{C}$ and the supernatant assayed by ELISA. ${ }^{35}$ Each sample of saliva and jejunal fluid was tested in duplicate at three fivefold dilution steps. All saliva and jejunal fluid samples were diluted in PBS containing $0.05 \%$ Tween 20 (Polysorbatum 20, Apoteksbolaget, Sweden) (PBS-Tween). Polystyrene microtitre plates (M 129B, Dynatech) were coated overnight with anti-immunoglobulins at room temperature and stored at $4^{\circ} \mathrm{C}$ until used. Each well was coated with $100 \mu$ l of rabbit immunoglobulins directed toward human IgM 
$(2.55 \mu \mathrm{g} / \mathrm{ml})$ ( $\mu$ specific, Dakopatts), IgG $(2.85 \mu \mathrm{g} / \mathrm{ml})$ ( $\gamma$ specific, Dakopatts), IgA (1.5 $\mu \mathrm{g} / \mathrm{ml}$ ) ( $\alpha$ specific, Dakopatts), or secretory component $(0.85 \mu \mathrm{g} / \mathrm{ml})$ (Dakopatts) in 0.1

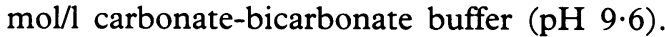
The microtitre plates coated with antibodies against secretory component were blocked with $100 \mu$ l bovine serum albumin (Sigma), 5 $\mathrm{mg} / \mathrm{ml}$, for four hours at room temperature. Saliva and jejunal samples, diluted 1:1250, $1: 6250,1: 31250$ for $\operatorname{sgA}$ and $\operatorname{IgA}$, and $1: 250$, $1: 1250,1: 6250$ for IgG and IgM, were added to the microtitre plate wells in a volume of $100 \mu \mathrm{l}$ and incubated overnight at room temperature.

Between the various incubation steps, the wells were rinsed five times with saline containing $0.05 \%$ Tween 20 (saline-Tween). Alkaline phosphatase (ALP) conjugated immunoglobulin fractions $(100 \mu \mathrm{l})$ of monospecific rabbit antisera to human $\operatorname{IgM}, \operatorname{IgG}$, and IgA (Dakopatts) diluted 1:1000 in salineTween were added and incubated for three hours at room temperature. After the final wash, disodium p-nitrophenyl phosphatase, 1 $\mathrm{mg} / \mathrm{ml}$ (Sigma) in $10 \%$ diethanolamine buffer was added and the absorbance measured at $405 \mathrm{~nm}$ at 10 minute intervals.

Colostrum was collected from five individuals and pooled. The purification of IgA from colostrum was performed by removing IgG and IgM by affinity chromatography using cyanogen bromide (CNBr)-activated Sepharose 4B (Pharmacia, Uppsala, Sweden). The contamination by $\operatorname{IgM}$ and IgG was below the background value and could not be detected by ELISA. The purified colostrum IgA was used as a reference standard for quantitation of $\operatorname{sIgA}$ and IgA. For measurements of IgG and IgM, standard human serum (Lot $041015 \mathrm{~F}$, Behringwerke) served as standard. All standards were diluted in PBS-Tween in sixfold dilution steps. Duplicate samples of 100 $\mu l$ each were used.

\section{DETERMINATION OF SERUM ANTI-GLIADIN} ANTIBODIES

Anti-gliadin antibodies were assayed with a solid phase ELISA. ${ }^{36}$ Microtitre plates were coated with $50 \mu \mathrm{g} / \mathrm{ml}$ gliadin (Sigma) dissolved in $70 \%$ ethanol. The plates were incubated for 60 minutes with serum diluted $1: 10$ in PBS containing $0.5 \%$ human serum albumin, and then washed. ALP conjugated rabbit antihuman IgG or IgA (Dakopatts) was used in appropriate dilutions. The absorbance was read spectrophotometrically. All serum samples were tested in duplicate. The reference values were $\leqslant 47$ units for IgG antigliadin antibodies and $\leqslant 30$ units for IgA antigliadin antibodies.

CLASS AND SUBCLASS SPECIFIC

DETERMINATIONS OF RF

Levels of IgM RF and IgG RF were determined using a diffusion-in-gel ELISA (DIG-ELISA) as previously described. ${ }^{37}$ Briefly, the inner surfaces of polystyrene Petri dishes were coated with $25 \mu \mathrm{g} / \mathrm{ml}$ of heat aggregated rabbit IgG. Melted agar was then poured into each dish. Wells $3 \mathrm{~mm}$ in diameter were punched in the gel and filled with the serum samples. After incubation at room temperature for 66 hours in a humid atmosphere, the agar was removed. The respective affinity purified, biotinylated $\mathrm{F}\left(\mathrm{ab}^{\prime}\right)_{2}$ fragments of anti-human $\operatorname{IgG}$ or $\operatorname{IgM}$ (Dakopatts), diluted 1:1000 in PBS-Tween were then poured into the dishes. After a two hour incubation, the dishes were rinsed, reincubated for a further one hour with $1 \mu \mathrm{g} / \mathrm{ml}$ horseradish peroxidase labelled avidin (Sigma) and rinsed; finally, melted $1 \%$ agar, containing $0.05 \%$ paraphenylenediamine and $0.01 \%$ $\mathrm{H}_{2} \mathrm{O}_{2}$ was poured into each dish. Positive reactions were recognised as gradually developing, brownish, circular areas. All the plates were photographed after 15 minutes and the diameters of the coloured areas were measured with a ruler to the nearest $\mathrm{mm}$. Reference levels for RF isotypes have been established in a previous study. ${ }^{20}$

To assess RF levels of IgA subclasses, the DIG-ELISA assay was used, with $5 \mu \mathrm{g} / \mathrm{ml}$ monoclonal anti-IgA1 or anti-IgA2 (Nordic) antibodies instead of class specific reagents. After two hours incubation the dishes were rinsed and reincubated with $\mathrm{F}\left(\mathrm{ab}^{\prime}\right)_{2}$ fragments of affinity purified and biotinylated rabbit antimouse IgG (Dakopatts) diluted 1:1000 in PBS-Tween. All the subsequent steps were as for determination of IgG and IgM RF.

IgA RF analysis was performed using a commercial sandwich enzyme immunoassay (SELISA) (Cambridge Life Sciences, Ely, Cambridgeshire, UK), according to the instructions of the manufacturer. Horse IgG was used as antigen and anti-IgA peroxidase as conjugate. All samples were tested in duplicate. Serum samples with IgA RF concentrations $<15$ units/ml were considered negative according to the reference values of the laboratory.

STATISTICAL ANALYSIS

Non-parametric two tailed tests were used. Wilcoxon signed rank test was used for comparisons of variables before and after SASP therapy and Spearman's rank correlation test was used for correlation purposes. Values of $p \leqslant 0.05$ were considered significant. The calculations were performed using css: STATISTICA $^{\mathrm{TM}}$ software (StatSoft, Inc, Tulsa, OK, USA).

\section{Results}

Three of the original 21 patients had to stop SASP therapy because of side effects and their data were therefore excluded from comparisons of the variables before and after therapy. In one of these three patients, all tests before therapy were performed and are included in the correlation analysis before therapy. One patient refrained from a second sampling of jejunal aspirate and one serum for analysis of IgG subclasses was lost. 
DISEASE ACTIVITY

The patients responded to SASP treatment with a significant decrease in inflammatory activity measured by acute phase reactants and disease activity index. ${ }^{28}$ No patients deteriorated during therapy. Disease activity index decreased from 71 (33-173) index units (median and range) before, to 27 (3-68) units after SASP treatment $(p<0.001)$. Serum concentrations of orosomucoid decreased from $1.42(1.02-3.12)$ to $0.89(0.58-1.67) \mathrm{g} / 1$ $(\mathrm{p}<0.001)$ and the ESR decreased from 46 $(16-90)$ to $16(6-48) \mathrm{mm} / 1 \mathrm{st} \mathrm{h}(\mathrm{p}<0.001)$.

\section{SERUM IMMUNOGLOBULINS}

Table 1 shows the serum concentrations of immunoglobulins and their subclasses before and after SASP therapy. Before therapy, the median value for IgA in the RA patients was increased compared with the reference values of the laboratory, while remaining immunoglobulin concentrations were within the normal range. Total IgA and total IgG and their respective subclasses all decreased although the

Table 1 Serum concentrations of immunoglobulins, their subclasses, and IL-6 in 18 patients with RA before and after 16 weeks of SASP therapy

\begin{tabular}{|c|c|c|c|}
\hline & Before $S A S P$ & After 16 weeks of $S A S P$ & $p^{\star}$ \\
\hline 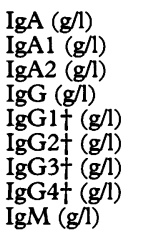 & $\begin{array}{c}4 \cdot 15(1 \cdot 70-5 \cdot 95) \\
1 \cdot 47(0 \cdot 48-4 \cdot 42) \\
0 \cdot 26(0 \cdot 07-1 \cdot 34) \\
14 \cdot 2(8 \cdot 0-22 \cdot 1) \\
11 \cdot 3(4 \cdot 4-16 \cdot 5) \\
3 \cdot 7(1 \cdot 5-5 \cdot 6) \\
0.7(0 \cdot 3-2 \cdot 7) \\
0.60(\mathrm{ND} \ddagger-1 \cdot 47) \\
1.82(0.40-4 \cdot 46)\end{array}$ & $\begin{array}{c}2 \cdot 82(1 \cdot 20-5 \cdot 57) \\
0.92(0 \cdot 41-5 \cdot 55) \\
0.20(0.04-0.75) \\
12 \cdot 8(6 \cdot 6-21 \cdot 9) \\
9 \cdot 3(4 \cdot 5-19 \cdot 2) \\
3 \cdot 1(0 \cdot 8-5 \cdot 8) \\
0.6(0 \cdot 2-1 \cdot 3) \\
0.36(\mathrm{ND} \ddagger-1.01) \\
1.80(0.54-4.02)\end{array}$ & $\begin{array}{l}0.0004 \\
0.07 \\
0.03 \\
0 \cdot 006 \\
0 \cdot 02 \\
0 \cdot 002 \\
0 \cdot 001 \\
0.0007 \\
0 \cdot 23\end{array}$ \\
\hline IL-6 (pg/ml) & $16(N D S-130)$ & 12 (NDq-35) & $0 \cdot 12$ \\
\hline
\end{tabular}

Values are median (range). ${ }^{\star}$ Comparison before $v$ after SASP therapy (Wilcoxon signed rank test).

$\lceil n=17 . \mathrm{ND}=$ Not detectable: $\ddagger$ in $1 / 17$ patients; $\oint$ in $4 / 18$ patients; $\uparrow$ in $7 / 18$ patients.

Table 2 Immunoglobulin concentrations in saliva and jejunal aspirates in 18 and 17 patients, respectively, with $R A$, before and after 16 weeks of SASP therapy

\begin{tabular}{lccc}
\hline & Before SASP & After 16 weeks of SASP & $p^{\star}$ \\
\hline Saliva (mg/l) & & & \\
Total IgA & $386(189-965)$ & $382(110-693)$ & $0 \cdot 10$ \\
sIgA & $261(150-831)$ & $253(94 \cdot 0-565)$ & $0 \cdot 32$ \\
IgG & $20(2 \cdot 6-88 \cdot 0)$ & $23(1 \cdot 4-94 \cdot 5)$ & $0 \cdot 37$ \\
IgM & $7 \cdot 5(1 \cdot 7-29 \cdot 4)$ & $5 \cdot 7(1 \cdot 1-31 \cdot 6)$ & $0 \cdot 29$ \\
Jejunum (mg/l) & & & \\
Total IgA & $64(3 \cdot 8-200)$ & $40(1 \cdot 3-239)$ & $0 \cdot 16$ \\
sIgA & $38(0 \cdot 4-134)$ & $24(0 \cdot 2-122)$ & $0 \cdot 21$ \\
IgG & $28(1 \cdot 0-78 \cdot 0)$ & $14(\mathrm{ND} \neq-87 \cdot 6)$ & $0 \cdot 55$ \\
IgM & $38($ NDS-154) & $14($ NDI-252) & $0 \cdot 26$ \\
\hline
\end{tabular}

Values are median (range). ${ }^{\star}$ Comparison before $v$ after SASP therapy (Wilcoxon signed rank

test). $=$ Not detectable: $\ddagger$ in $2 / 17$ patients; $\S$ in $1 / 17$ patients; $\uparrow$ in $3 / 17$ patients.

Table 3 Serum levels of $I g A R F, I g A 1 R F, \operatorname{Ig} A 2 R F, \operatorname{Ig} G R F, I g M R F$, and $\operatorname{Ig} A$ and IgG anti-gliadin antibodies ( $A G A$ ) in 18 patients with rheumatoid arthritis before and after 16 weeks of $S A S P$ therapy

\begin{tabular}{lccl}
\hline & Before SASP & After 16 weeks of SASP & $p^{\star}$ \\
\hline IgA RF (U/ml) & 124 (ND-600) & 50 (ND-600) & 0.00098 \\
IgA1 RF (mm) & 9 (ND-14) & 8 (ND-14) & 0.0035 \\
IgA2 RF (mm) & ND (ND-8) & ND (ND-9) & 0.29 \\
IgG RF (mm) & 5 (ND-16) & 3 (ND-14) & 0.28 \\
IgM RF (mm) & 8 (ND-14) & $6 \cdot 5$ (ND-14) & 0.0019 \\
IgA AGA (U) & 20.3 (ND-165) & $12 \cdot 6$ (ND-84.2) & 0.001 \\
IgG AGA (U) & 3.0 (ND-36) & $2 \cdot 8$ (ND-24.0) & 0.07 \\
\hline
\end{tabular}

Values are median (range). ${ }^{\star}$ Comparison before $v$ after SASP therapy (Wilcoxon signed rank

test). $=$ Not detectable. decrease for IgA1 did not reach statistical significance. The median concentration of IgM was unaltered by SASP. No correlations were observed between the concentration of any immunoglobulin class or subclass and age, disease activity index, serum orosomucoid, or ESR before SASP therapy. Striking correlations were observed between the reductions in total IgA and total IgG $(r=0.86 ; \mathrm{p}=0.00005)$, and between the reductions in IgA1 and total IgG $(r=0.52 ; \mathrm{p}=0.028)$.

SERUM IL-6

Serum IL-6 decreased, although not significantly, in the RA patients during SASP therapy (table 1). Because determination of small concentrations of IL-6 $(<20 \mathrm{pg} / \mathrm{ml})$ is unreliable in our assay system, we examined the seven RA patients having original IL-6 values $\geqslant 20 \mathrm{pg} / \mathrm{ml}$. In these patients, IL-6 concentration decreased from 34 (20-130) $\mathrm{pg} / \mathrm{ml}$ (median and range) before therapy to 16 (range from not detectable to 20) $\mathrm{pg} / \mathrm{ml}$ after therapy $(p=0.018)$. At the initiation of therapy, serum IL-6 values showed a weak correlation with serum orosomucoid $(r=0.45$; $\mathrm{p}=0.05$ ), but not with serum concentrations of immunoglobulins or rheumatoid factors. However, the reduction in IL-6 found after SASP treatment correlated with the reduction in total serum IgA $(r=0.56 ; \mathrm{p}=0.015)$ and with that of serum IgG $(r=0.46 ; \mathrm{p}=0.056)$.

\section{IMMUNOGLOBULINS IN SALIVA AND JEJUNAL} ASPIRATES

As expected, salivary immunoglobulins were primarily IgA; this was less true for jejunal fluid (table 2). No correlations were observed between salivary and jejunal concentrations of immunoglobulin, or between salivary or jejunal immunoglobulins and disease activity measurements. Furthermore, no convincing associations between salivary or jejunal and peripheral blood immunoglobulin concentrations were seen at the initiation of therapy, except for a modest correlation between salivary $\operatorname{IgM}$ and serum $\operatorname{IgM}$ values $(r=0.46$; $p=0.047$ ). The immunoglobulin levels in saliva and jejunal fluid did not change significantly after SASP therapy.

\section{ANTI-GLIADIN ANTIBODIES}

Six of 19 patients $(32 \%)$ had increased serum IgA anti-gliadin antibodies before therapy, and two of $18(11 \%)$ after SASP therapy; none had increased IgG anti-gliadin antibodies either before or after therapy. The serum levels of IgA anti-gliadin antibodies decreased significantly during SASP therapy, whereas the decrease in IgG anti-gliadin antibodies did not reach statistical significance (table 3 ). Serum levels of IgA anti-gliadin antibodies correlated weakly with serum IgA before therapy $(r=0.39$; $\mathrm{p}=0.095$ ), as did the reductions in IgA antigliadin antibodies and the reductions in serum IgA after SASP therapy $(r=0.42 ; \mathrm{p}=0.084)$. No corresponding correlation regarding IgG 
anti-gliadin antibodies and serum IgG was observed $(r=0.22 ; \mathrm{p}=0.36$ and $r=0.27$; $\mathrm{p}=0 \cdot 26$, respectively). IgA anti-gliadin antibodies in serum showed a weak correlation $(r=0.50 ; \mathrm{p}=0.030)$ with $\operatorname{sigA}$ in jejunal fluid. In contrast, no correlations with sIgA levels in saliva could be demonstrated $(r=0.22$; $\mathrm{p}=0 \cdot 36)$.

\section{RHEUMATOID FACTORS}

All patients had previously been seropositive for IgM RF according to the inclusion criteria. At the start of the present study, 18/19 (95\%) were positive for IgM RF, $12 / 19$ (63\%) for IgG RF and $17 / 19$ (89\%) for IgA RF. Of those positive for IgM RF, 11/18 (61\%) were also positive for IgG RF and $17 / 18$ (94\%) for IgA RF. All 11 patients who were positive for both IgM RF and IgG RF were also positive for IgA RF. The only patient negative for IgM RF was positive for IgG RF but negative for IgA RF. Regarding IgA RF subclasses, 16/19 (84\%) had IgA1 RF and 5/19 (26\%) IgA2 RF. All patients with IgA2 RF also had IgA1 RF. After SASP therapy, $15 / 18$ patients $(83 \%)$ were positive for IgM RF, 8/18 (44\%) for IgG RF, $14 / 18(78 \%)$ for IgA RF, $14 / 18(78 \%)$ for IgA 1 $\mathrm{RF}$, and $2 / 18(11 \%)$ for IgA2 RF.

Table 3 shows serum levels of RF isotypes. After SASP therapy, highly significant reductions in IgA RF, IgA1 RF, and IgM RF were noted, but only minor reductions in IgA2 $\mathrm{RF}$ and IgG RF.

\section{Discussion}

In the present study, SASP treatment of RA patients did not affect the amounts of IgA, sIgA, IgG or IgM produced in mucosal compartments. In contrast, the reduction in serum IgA was highly significant, as was that in serum IgG. In addition, serum IgA RF, IgM RF and IgA class anti-gliadin antibody levels decreased significantly as a consequence of SASP administration.

$\operatorname{IgA}$, which is the major immunoglobulin in secretory glands and the gastrointestinal tract, ${ }^{17}$ appears mostly in a polymeric form in secretions and is synthesised locally. ${ }^{38}$ In mucosal tissues, polymeric $\operatorname{IgA}$ (pIgA) is transported to the lumen after binding to a glycoprotein secretory component (SC) produced by and located at the basolateral cell membrane surface of epithelial cells. The pIgA-SC complexes are thereafter translocated by endocytosis to the lumen. ${ }^{16}$ Monomeric $\operatorname{IgA}(\mathrm{mIgA})$ is found in intestinal juices in small amounts, but may increase in gut diseases as a result of leakage of extravascular proteins into the lumen. ${ }^{39}$ In serum, the IgA1 subclass predominates and amounts to more than $80 \%$ of IgA, whereas the IgA2 subclass accounts for up to $50 \%$ of the total IgA in secretions. ${ }^{40}$

The median serum IgA in our RA patients was increased. Increased serum IgA occurs frequently in $\mathrm{RA}^{41-44}$ and has been interpreted by some authors as reflecting a stimulated mucosal immune system. ${ }^{45}$ However, no substantial proof for this hypothesis exists.
Serum IgA, like IgG and $\operatorname{Ig} M$, is mainly derived from the bone marrow, with smaller contributions from the spleen and peripheral lymph nodes, ${ }^{46} 47$ and its synthesis is largely independent of sIgA concentrations. This fact, in conjunction with the observed simultaneous and significantly intercorrelated changes in serum IgA and serum IgG (but not $\operatorname{sIgA}$ in saliva and jejunal fluid) induced by SASP, strongly suggests that SASP affects the systemic lymphoid compartment, and hardly reflects immunomodulatory effects at the intestinal level.

The decrease in IL-6 in serum after SASP therapy was correlated with the decrease in IgA and IgG concentrations in serum. Besides inducing acute phase proteins, IL- 6 is a potent $B$ cell differentiation factor ${ }^{48}$ and is closely involved in the regulation of $\operatorname{IgA}$ and $\operatorname{IgG}$ production. This raises the possibility that the decreased serum immunoglobulin concentrations observed during SASP treatment may depend on SASP inhibiting IL-6 production in the synovial membrane and other loci. The proposed downregulation of $\mathrm{B}$ cells in the systemic lymphoid compartment may also be a direct effect of the drug on $B$ cells or regulatory $T$ cells, or both, as shown previously in vitro. ${ }^{36}$ Alternatively, the drug might influence the reactivity of antigen presenting cells.

Previous clinical studies of the effects of SASP on serum immunoglobulins in rheumatoid arthritis and ankylosing spondylitis have shown varying results. Reductions in none, one, two or all three of the IgA, IgG, or IgM classes have been reported ${ }^{39-62}$ in addition to SASP induced selective IgA deficiency, IgA and IgG2 deficiency, and panhypogammaglobulinaemia. $^{7-9}$ An association between decreasing immunoglobulin concentrations and a favourable clinical response to SASP therapy has been reported ${ }^{93}$ and corroborates our observations.

No apparent correlations between concentrations of immunoglobulins in serum and saliva or jejunal fluid were observed. This agrees with the view that the systemic and mucosal immune systems are separate. Our observations in serum do not exclude the possibility that SASP also affects immunoglobulin productivity in salivary glands and the small intestinal mucosa, although we found no evidence of such an effect. Somewhat contradictorily, Feltelius et al have shown, using the enzyme linked immunospot technique, that the numbers of IgA-producing peripheral blood lymphocytes were reduced after SASP treatment. ${ }^{63}$ Some of these cells are proposed to originate from the gut and therefore reflect mucosal immunity; ${ }^{64}$ however, as a considerable proportion of these circulating IgA-committed B cells originate from the bone marrow, the results of Feltelius et al may instead reflect the effect of SASP on systemic immunity. Indeed, an inhibitory effect of SASP on circulating IgG-committed $B$ cells has been demonstrated using the same technique. ${ }^{65}$

Six of our patients had increased serum IgA anti-gliadin antibody levels. The serum levels 
of IgA anti-gliadin antibodies decreased significantly during SASP therapy. Our results favour the concept that this decrease simply mirrors the overall decreased production of IgA in the systemic compartment. Accordingly, SASP may regulate the production of both IgA anti-gliadin antibodies and total IgA in similar way, probably by affecting bone marrow, spleen and lymph node immunoglobulin-producing B cells. The lack of effect of SASP on jejunal IgA production further favours this concept.

Circulating IgA RF, IgA1 RF, and IgM RF all decreased during treatment with SASP. Rheumatoid factor has been observed in serum, synovial fluid, and mucosal secretions in RA patients, ${ }^{66-68}$ and production by mononuclear cells in peripheral blood, bone marrow, synovial tissues, and salivary glands has been demonstrated. ${ }^{25} 6970$ IgA $R F$ is predominantly polymeric ${ }^{71}$ and has therefore been considered to originate from mucosal tissues. However, more recent studies have shown that this RF isotype is also present and may be produced in nonmucosal compartments. ${ }^{25} 7071$ Furthermore, evidence for local production of both IgA1 RF and IgA2 RF subclasses in mucosal (saliva) and in non-mucosal (synovial fluid) compartments has been put forward, and a predominance of $\operatorname{IgA} 2 \mathrm{RF}$ production in salivary glands compared with synovial fluid was observed. ${ }^{25}$

Reduction of RF has been demonstrated after treatment with SASP and other antirheumatic agents, for example D-penicillamine, gold, and methotrexate. ${ }^{3} 535572-76$ Because the changes in IgA RF and IgM RF did not correlate with the respective changes in serum immunoglobulin concentrations in the SASP treated patients (data not shown), the reductions in RF are not considered to be related to the changes in the overall production of immunoglobulins. Rather, it seems plausible that SASP directly inhibits RF production, an influence that is selective for IgA RF and IgM RF-committed B cells, as synthesis of IgG RF was not affected. A similar differential effect of antirheumatic drugs on the various RF classes has also been demonstrated for penicillamine ${ }^{73}$ and gold. ${ }^{74}$ The observed significant reduction in IgA1 RF as opposed to IgA2 RF induced by SASP treatment may further indicate a differential effect of SASP on systemic and mucosal immunity.

In summary, the results from this study indicate that SASP exerts powerful inhibitory effects on systemic IgA and IgG production, but is devoid of similar effects in mucosal tissues, judged by its lack of effect on immunoglobulin production in saliva and jejunal fluid. The effect of SASP on circulating levels of IgA anti-gliadin antibodies mirrors that on systemic immunity and favours the previously presented concept that these antibodies are not of mucosal origin. ${ }^{77} 78$ Finally, SASP seems selectively to inhibit production of $\operatorname{IgA}$ and IgM RF independently of its effect on corresponding serum immunoglobulin concentrations.
We are most grateful to Marja Winberg for expert secretarial help. This study was supported by grants from the Swedish Medical Research Council (MFR), Swedish Association Against Rheumatism, Professor Nanna Svartz' Foundation, King Gustaf V's 80-year Fund, the Alex and Eva Wallström's Foundation, the Ulla and Gustaf af Ugglas' Fund, Börje Dahlin's Fund, and 'Förenade Liv' Mutual Group Life

Assurance Company, Stockholm, Sweden.

1 Stenson W F, Mehta J, Spilberg I. Sulfasalazine inhibition of binding of $\mathrm{N}$-formyl-methionyl-leucyl-phenylalanine (fMLP) to its receptor on human neutrophils. Biochem Pharmacol 1984; 33: 407-12.

2 Kanerud L, Hafström I, Ringertz B. Effect of sulphasalazine and sulphapyridine on neutrophil superoxide production: role of cytosolic free calcium. Ann Rheum Dis 1990; 49: role of cy

3 Symmons D P M, Salmon $M$, Farr $M$, Bacon P A Sulfasalazine treatment and lymphocyte function in patients with rheumatoid arthritis. $\mathcal{F}$ Rheumatol 1988; 15: 575-9.

4 Comer S S, Jasin H E. In vitro immunomodulatory effects of sulphasalazine and its metabolites. F Rheumatol 1988; 15: $580-6$.

5 Sheldon P, Webb C, Grindulis K A. Effect of sulphasalazine and its metabolites on mitogen induced transformation of lymphocytes-clues to its clinical action? Br f Rheumatol 1988; 27: 344-9.

6 Imai F, Suzuki T, Ishibashi T, Dohi Y. Effect of sulfasalazine on B cells. Clin Exp Rheumatol 1991; 9: 259-64.

7 Delamere J P, Farr M, Grindulis K A. Sulphasalazine induced selective IgA deficiency in rheumatoid arthritis. $B M f$ 1983; 286: 1547-8.

8 Leickly F E, Buckley R H. Development of IgA and IgG2 subclass deficiency after sulfasalazine therapy. $\mathcal{f}$ Pediatr 1986; 108: 481-2

9 Farr M, Kitas G D, Tunn E J, Bacon P A Immunodeficiencies associated with sulphasalazine therapy in inflammatory arthritis. $\mathrm{Br} \mathcal{F}$ Rheumatol 1991; 30: 413-7.

10 Sheldon P, Pell P. Comparison of the effect of oral sulphasalazine, sulphapyridine and 5-amino-salicyclic sulphasalazine, sulphapyridine and 5-amino-salicyclic acid on the in vivo antibody response to oral and

11 Kanerud L, Scheynius A, Hafström I. Evidence of a local intestinal immunomodulatory effect of sulfasalazine in rheumatoid arthritis. Arthritis Rheum 1994; 37: 1138-45.

12 Svartz N. The treatment of rheumatic polyarthritis with acid azo compounds. Rheumatism 1948; 4: 180-5.

13 Panush R D, Stroud R M, Webster E M. Food-induced (allergic) arthritis. Inflammatory arthritis exacerbated by milk. Arthritis Rheum 1986; 29: 220-6.

14 Segal A W, Isenberg D A, Hajirousou V, Tolfree S, Clark J, Snaith M L. Preliminary evidence for gut involvement in the pathogenesis of rheumatoid arthritis? $B r f$ Rheumatol 1986; 25: 162-6.

15 Bjarnason I, Hopkinson N, Zanelli G, et al. Treatment of non-steroidal anti-inflammatory drug induced enteropathy. Gut 1990; 31: 777-80

16 Brandtzaeg P, Halstensen $\mathrm{T} S$, Kett $\mathrm{K}$, et al. Immunobiology and immunopathology of human gut mucosa: Humoral immunity and intraepithelial lymphocytes. Gastroenterology 1989; 97: 1562-84.

17 Crabbé $P$ A, Heremans J F. The distribution of immunoglobulin-containing cells along the human gastrointestinal tract. Gastroenterology 1966; 51: 305-16.

18 Mestecky J, McGhee J R, Arnold R R, Michalek S M, Prince $\mathrm{S} \mathrm{J}$, Babb J L. Selective induction of an immune response in human external secretions by ingestion of bacterial in human external secretions by ingest

19 Trollmo $\mathrm{C}$, Carlsten H, Tarkowski $\mathrm{A}$. The gut as an inductive site for articular and extraarticular immune inductive site for articular and extraarticular immune response in $377-82$.

20 Tarkowski A, Nilsson L- $\AA$. Isotype-specific measurement of rheumatoid factor with reference to clinical features of rheumatoid arthritis. F Clin Lab Immunol 1983; 12: 129-35.

21 Teitsson I, Withrington R H, Seifert M H, Valdimarsson $H$ Prospective study of early rheumatoid arthritis. I. Prognostic value of IgA rheumatoid factor. Ann Rheum Dis 1984; 43: 673-8.

22 Westedt M-L, Daha M R, Baldwin W M III, Stijnen T, Cats A. Serum immune complexes containing IgA appear to predict erosive arthritis in a longitudinal study in predict erosive arthritis in a longitudinal study in

23 van Zeben $D$, Hazes J M W, Zwinderman A H, Cats A, van der Voort E A M, Breedveld F C. Clinical significance of rer Voort E A M, Breedveld F C. Clinical significance of rheumatoid factors in early rheumatoid arthritis: results

24 Hirsch H Z, Tarkowski A, Koopman W J, Mestecky J. Local production of IgA- and IgM-rheumatoid factors in adult peridontal disease. F Clin Immunol 1989; 9: 273-8.

25 Otten $H$ G, Daha M R, van Laar J M, de Rooy H H, Breedveld F C. Subclass distribution and size of human IgA rheumatoid factor at mucosal and nonmucosal sites. Arthritis Rheum 1991; 34: 831-9.

26 Lúdviksson B R, Jónsson T, Erlendsson K, Sigfússon Á. Disease manifestations in patients with isolated elevation of IgA rheumatoid factor. Scand $\mathcal{F}$ Rheumatol 1992; 21: $1-4$. 
27 Ropes M W, Bennett G A, Cobb S, Jacox R, Jessar R A Diagnostic criteria for rheumatoid arthritis. Ann Rheum Dis 1953; 18: 49-53.

28 Kanerud L, Hafström I, Berg A. Effects of antirheumatic treatment on gastric secretory function and salivary flow in patients with rheumatoid arthritis. Clin Exp Rheumatol 1991; 9: 595-601.

29 Tarkowski A, Moldoveanu Z, Koopman W J, Radl J, Haaijman J J, Mestecky J. Cellular origins of human polymeric and monomeric IgA: enumeration of single cells secreting polymeric IgA1 and IgA2 in peripheral cells secreting polymeric IgA1 and IgA2 in peripheral blood, bone marrow, spleen, gingi

30 Russel M W, Brown T A, Radl J, Haaijman J J, Mestecky $\mathrm{J}$. Assay of human IgA subclass antibodies in serum and secretions by means of monoclonal antibodies. F Immunol Methods 1986; 87: 87-93

31 Trollmo C, Carlsten H, Tarkowski A. Intra-articular immunization induces strong systemic immune responses in humans. Clin Exp Immunol 1990; 82: 384-9.

32 Arden L A, De Groot E R, Schaap O L, Lansdorp P M. Production of hydridoma growth factor by human monocytes. Eur F Immunol 1987; 17: 1411-6.

33 Helle M, Boeije L, Aarden L A. Functional discrimination between interleukin 6 and interleukin 1 . Eur $\mathcal{f}$ Immunol 1988; 18: 1535-40

34 Kanerud L, Scheynius A, Nord C E, Hafström I. Effect of sulphasalazine on gastrointestinal microflora and on mucosal HSP60 expression in patients with rheumatoid arthritis. Br f Rheum 1994; 33: 1039-48.

35 Engvall E, Perlmann P. Enzyme-linked immunosorbent assay, ELISA. III. Quantitation of specific antibodies by enzyme-labeled anti-immunoglobulin in antigen-coated tubes. F Immunol 1972; 109: 129-35.

36 Grodzinsky E, Hed J, Lieden G, et al. Presence of IgA and IgG antigliadin antibodies in healthy adults as measured by micro-ELISA immunoassay. Int Arch Allergy Appl Immunol 1990; 92: 119-26.

37 Tarkowski A, Bjursten L M, Nilsson L-Å, Nygren H. False positive results in class-specific rheumatoid factor $(\mathrm{RF})$ assays due to interaction between RF and Fc fragments of anti-immunoglobulin indicator reagents. $f$ Immunol Methods 1983; 58: 171-82.

38 Jonard P P, Rambaud J C, Dive C, Vaerman J P, Galian A, Delacroix D L. Secretion of immunoglobulins and plasma proteins from the jejunal mucosa. 7 Clin Invest 1984; 74: 525-35

39 Haneberg B, Aarskog D. Human faecal immunoglobulins in healthy infants and children, and in some with diseases affecting the intestinal tract or the immune system. Clin Exp Immunol 1975; 22: 210-22.

40 Delacroix D L, Dive C, Rambaud J C, Vaerman J P. IgA subclasses in various secretions and in serum. Immunology 1982; 47: 383-5.

41 Claman H N, Merrill D. Serum immunoglobulins in rheumatoid arthritis. I Lab Clin Med 1966; 67: 850-4.

42 Veys E M, Claessens H E. Serum levels of IgG, IgM and IgA in rheumatoid arthritis. Ann Rheum Dis 1968; 27: 431-40

43 Komatsubara Y, Hiramatsu S, Hongo I, Maeda A, Soda T, Botan Y. Multi-variate analysis of serum protein in rheumatoid arthritis. Scand $\mathcal{F}$ Rheumatol 1976; 5: 97-102.

44 Pillemer S R, Reynolds W J, Yoon S J, Perera M, Newkirk $M$, Klein $M$. IgA related disorders in rheumatoid arthritis. 7 Rheumatol 1987; 14: 880-6.

45 Cowling P, Ebringer R, Ebringer A. Association of inflammation with raised serum IgA in ankylosing spondylitis. Ann Rheum Dis 1980; 39: 545-9.

46 Conley M E, Delacroix D L. Intravascular and mucosal immunoglobulin A: Two separate but related systems of immune defence? Ann Int Med 1987; 106: 892-9.

47 Kutteh W H, Prince S J, Mestecky J. Tissue origins of human polymeric and monomeric IgA. F Immunol 1982; 128: $990-5$.

48 Hirano T, Yasukawa $\mathrm{K}$, Harada $\mathrm{H}$, et al. Complementary DNA for a novel human interleukin (BSF-2) that induces B lymphocytes to produce immunoglobulin. Nature 1986; 324: $73-6$.

49 Bird H A, Dixon J S, Pickup M E, et al. A biochemical assessment of sulphasalazine in rheumatoid arthritis. $\mathcal{F}$ Rheumatol 1982; 9: 36-45.

50 Farr M, Tunn E, Crockson A P, Bacon P A. The long term effects of sulphasalazine in the treatment of rheumatoid effects of sulphasalazine in the treatment of rheumatoid arthritis and a comparative

51 Pelisková Z, Vácha J, Trnavský K. Sulphasalazine in the treatment of rheumatoid arthritis. $Z$ Rheumatol 1985 ; 44: $263-6$.

52 Nuver-Zwart I H, van Riel P L C M, van de Putte L B A, Gribnau F W J. A double blind comparative study of sulphasalazine and hydroxychloroquine in rheumatoid arthritis: evidence of an earlier effect of sulphasalazine. Ann Rheum Dis 1989; 48: 389-95.

53 Chalmers I M, Sitar D S, Hunter T. A one-year, open, prospective study of sulfasalazine in the treatment of rheumatoid arthritis: adverse reactions and clinical response in relation to laboratory variables, drug and metabolite serum levels and acetylator status. $\mathcal{f}$ Rheumatol 1990; 17: 764-70.
54 Samanta A, Webb C, Grindulis K A, Fleming J, Sheldon $P$ J. Sulphasalazine therapy in rheumatoid arthritis: qualitative changes in lymphocytes and correlation with clinical response. Br F Rheumatol 1992; 31: 259-63.

55 The Australian multicentre clinical trial group. Sulfasalazine in early rheumatoid arthritis. F Rheumatol 1992; 19: 1672-7.

56 Jorgensen C, Bologna C, Anaya J M, Reme T, Sany J. Variation in the serum IgA concentration and the production of IgA in vitro in rheumatoid arthritis treated by sulfasalazine. Rheumatol Int 1993; 13: 113-6.

57 Dougados M, Boumier P, Amor B. Sulphasalazine in ankylosing spondylitis: a double blind controlled study in 60 patients. BMF 1986; 293: 911-4.

58 Feltelius N, Hällgren R, Sjöberg O. T lymphocytes in ankylosing spondylitis and the influence of sulphasalazine treatment. Clin Rheumatol 1987; 6: 545-52.

59 Nissilä $M$, Lehtinen K, Leirisalo-Repo $M$, Luukkainen $R$ Mutru O, Yli-Kerttula U. Sulfasalazine in the treatment of ankylosing spondylitis. Arthritis Rheum 1988; 31: 1111-6.

60 Davis M J, Dawes P T, Beswick E, Lewin I V, Stanworth D R. Sulphasalazine therapy in ankylosing spondylitis: its effect on disease activity, immunoglobulin $\mathrm{A}$ and the complex immunoglobulin A-alpha-1-antitrypsin. $\mathrm{Br} F$ Complex immunoglobulin

61 Fraser S M, Sturrock R D. Evaluation of sulphasalazine in ankylosing spondylitis - an interventional study. $\mathrm{Br} \mathscr{F}$ Rheumatol 1990; 29: 37-9.

62 Corkhill MM, Jobanputra P, Gibson T, MacFarlane D G A controlled trial of sulphasalazine treatment of chronic ankylosing spondylitis: failure to demonstrate a clinical effect. Br f Rheumatol 1990; 29: 41-5.

63 Feltelius N, Gudmundsson S, Wennersten L, Sjöberg O, Hällgren R, Klareskog L. Enumeration of IgA producing cells by the enzyme linked immunospot (ELISPOT) technique to evaluate sulphasalazine effects in inflammatory arthritides. Ann Rheum Dis 1991; 50: 369-71

64 Mestecky J. The common mucosal immune system and current strategies for induction of immune responses in external secretions. 7 Clin Immunol 1987; 7: 265-76.

65 Gudmundsson S, Feltelius N, Rogberg S, Smedegărd G, Klareskog L. In: Pathogenic and therapeutic aspects of rheumatoid arthritis. Thesis. Uppsala: Acta Universitatis Upsaliensis 1993; 416: V.

66 Elkon K B, Gharavi A E, Patel B M, Hughes G R V, Franke A. IgA and IgM rheumatoid factors in serum, saliva and other secretions: relationship to immunoglobulin ratios in systemic sicca syndrome and rheumatoid arthritis. Clin Exp Immunol 1983; 52: 75-84.

67 Zrein M, Weiss E, van Regenmortel M H V. Detection of rheumatoid factors of different isotypes by ELISA using biotinylated avian antibodies. Immunol Invest 1988; 17: 165-81.

68 Otten H G, Daha M R, de Rooij H H, Breedveld F C. Quantitative detection of class-specific rheumatoid Quantitative detection of class-specific rheumatoid factors using mouse monoclonal antibodies and the biotin/streptavidin

69 Koopman W J, Schrohenloher R D, Crago S S, Spaldin D M, Mestecky J. IgA rheumatoid factor synthesis by dissociated synovial cells: characterization and relationship to IgM rheumatoid factor synthesis. Arthritis Rheum 1985; 28: 1219-27.

70 Otten H G, Daha M R, Dolhain R J E M, de Rooy H H Breedveld F C. Rheumatoid factor production by mononuclear cells derived from different sites of patients with rheumatoid arthritis. Clin Exp Immunol 1993; 94: with rhe $236-40$.

71 Schrohenloher R E, Koopman W J, Alarcón G S. Molecula forms of IgA rheumatoid factor in serum and synovial fluid of patients with rheumatoid arthritis. Arthritis Rheum 1986; 29: 1194-202.

72 Bluestone R, Goldberg L S. Effect of D-penicillamine on serum immunoglobulins and rheumatoid factor. $A n n$ Rheum Dis 1973; 32: 50-2.

73 Wernick R, Merryman P, Jaffe I, Ziff $M$. IgG and IgM rheumatoid factors in rheumatoid arthritis. Arthritis Rheum 1983; 26: 593-8.

74 Hanly J G, Hassan J, Whelan A, Feighery C, Bresnihan B. Effects of gold therapy on the synthesis and quantity of serum and synovial fluid IgM, IgG, and IgA rheumatoid arthritis factors in rheumatoid arthritis patients. Arthritis Rheum 1986; 29: 480-7.

75 Olsen NJ, Callahan LF, Pincus T. In vitro rheumatoid factor synthesis in patients taking second-line drugs for rheumatoid arthritis. Arthritis Rheum 1988; 31: 1090-6.

76 Alarcón GS, Schrohenloher R E Bartolucci A A, Ward J R Williams H J, Koopman W J. Suppression of rheumatoid factor production by methotrexate in patients with rheumatoid arthritis. Arthritis Rheum 1990; 33: 1156-61.

77 Colombel J F, Mascart-Lemone F, Nemeth J, Vaerman J P Dive C, Rambaud J C. Jejunal immunoglobulin and antigliadin antibody secretion in adult cocliac disease. $G u$ 1990; 31: 1345-9.

78 Engström P-E, Sundin U, Lavö B, et al. Class and subclassassociated specificity differences of anti-gliadin antibodies from mucosa and serum. Immunology 1992; 77: 604-8. 